\title{
Albanon
}

Revistë kulturore

\section{Vorre të harrueme në mërgim}

\author{
Ardian Ndreca
}

"Del viver ch'é un correre a la morte»

Dante Alighieri

Gjithçka m’erdhi papritmas para shumëvitesh, kur nji mik i huej, i palodhshëm në punën e tij me nxjerrë në pah letrat e vlerat e kulturës shqiptare, më bâni nji "kërkesë të çuditshme": me shkue me bâ nji vizitë ndër vorret protestante të Romës, për me gjetë nji të dhânë që i duhej me ngut.

Vorret e protestantëve në Romë, ose siç quhen ndryshe: Vorret jo katolike, gjinden ngjitë me piramiden e Kaio Qestit, njenit prej prefektave të Romës.

Piramida e Qestit ruen në gjinin e vet hinin e këtij prefekti të devotshëm të veprave të shenjta e të punëve botore dhe âsht ndërtue, siç lexohet te nji mbishkrim, në 330 ditë. E pra âsht nji piramidë mjaft e madhe, e naltë 36 metër e ka secilën brinjë nga 29 metër të gjatë. Vorret shtrihen në t'djathtë të rrugës Ostiense, në nji anë të përvujtë e disi të veçueme prej ecjes së pandalshme të njerzisë. Selvijat e denduna të tregojnë se ku kanë gjetë paqë, ata që jo feja, por mâ s'shumti bindjet politike dhe shoqnore i kanë bashkue, pa shikjue kombësinë e shumë herë as pozitën e pasunín.

Aty âsht vorros poeti i madh anglez John Keats e krejt afër, miku i tij besnik, konsulli britanik në Romë, piktori J. Severn. Pak mâ andej ka gjetë paqë edhe shpirti romantik i poetit P.B. Shelley, kurse nalt në hijen e qiparisave gjindet vorri i djalit të vetëm të Goethes: Augustit. Dihet që edhe vetë poeti i Weimar-it ka pasë dëshirue me u vorros në Qytetin e Amshuem. Nën mbishkrimet cirilike gjejmë edhe emnat e disa mbasardhësve të familjes Pushkin e Tolstoj. Afër tyne edhe babën e fisnikut rus që vrau Rasputinin, bahet fjalë Feliks Feliksoviç Jusupov-in. 
Në këto vorre âsht vorrosë edhe filozofi marksist Antonio Labriola e pak mâ andej edhe mâ i shquemi eksponent italian i teorisë komuniste: Antonio Gramsci.

Në ato vorre prehen tre shqiptarë të ndiem: Shefqet Verlaci, Mehdi Frashëri dhe Ali Këlcyra.

Tue kërkue mes rradhëve papritë u gjeta te kambët e njenit prej vorreve që kërkojsha. Ndjeva emocione tue pa të shkruem emnin e nji njeriu që ka qenë protagonist i historisë tonë kombtare:

Shefqet Verlaci, Elbasan 15/12/1877 - Zyrih 21/7/1946, pranë tij edhe i biri, Ismaili, i vdekun në Romë në vjetin 1985.

Dikur âsht thanë se ne shqiptarët e duem mâ fort njeni tjetrin kur jemi larg prej Shqipnijet, m’u duk gati kështu kur u përkula me lexue mâ mirë mbishkrimin e feudalit mâ të madh që ka pasë Shqipnija në shekullin e XX. M'u kujtuene fjalët e E. Hoxhës thanë atij katundarit të dalluem që i kishte shkue në shtëpi për vizitë: "Shkele, shkele me këpucët e tua këtë sixhadé, se e Shefqet Verlacit ka qenë”.

Fjalë me mend, prej atyne që shqiptarëve i prekin zemrën e i depërtojnë në shpirt: shkele, theje, digje, vidhe...

Ishe para vorrit t’atij Shefqet beut që nji herë e nji kohë kishte qenë mâ i madhi pronar tokash në Shqipní, jo politikan, por feudal me rrânjë të thella e me lidhje që gati e bâne mik me Zogun, mos ta prishte ky i fundit fejesen për me marrë princeshen hungareze të shtëpisë Appony. Ishte ai Verlac të cilin Këshilli i Regjencës e ngarkoi në mars të 1924 me formue qeverinë e re, mbasi Zogu, i plagosun prej Beqir Walterit me 23 shkurt, kishte dhanë dorëheqjen. Kjo gja zemëroi demokratët e anëtarët e Bashkimit të Avni Rustemit, që s'mund t'i durojshin aspak feudalët, edhe për shkakun se Vërlaci nuk vinte prej atyne politikanë që kishin ndërtue shtetin e ri shqiptar.

Duhet thanë veç se në qeverinë e tij mori pjesë si ministër arsimit edhe L. Gurakuqi. Kurse n'at' kohë Kuvendi Kushtetues kishte ndër misa të vet: Ahmet Zogun, Terenc Toçin, Rauf Ficon, Ali Këlcyrën, Bahri Omarin, Kostaq Kotte, Faik Konicën, Fan Nolin, Sejfi Vllamasin, Kol Tromaren, P. Ambroz Marlaskajn, Hil Mosin, Don Ndre Mjedjen, Shuk Gurakuqin, Nush Bushatin, Qazim Koculin, Luigj Gurakuqin e edhe Shefqet bej Verlacin. Por, pranvera e vjetit 1924 nuk premtonte gjana të mira për Beun e Elbasanit, së pari vrasja në Mamurras prej nji grupi banditësh e dy amerikanëve e mâ 


\section{Albanon}

\section{Revistë kulturore}

vonë vrasja e Avni Rustemit në Tiranë. Me 20 prill A. Rustemi do t’plagosej rândë me anë të nji atentati, e do të jepte shpirt në spital mbas dy ditësh.

Avniu, heroi i vjetit 1920, ai që qëroi prej faqes së dheut nji prej personazheve mâ negative të atyne vjetëve, kishte organizue nji shoqní, «Bashkimin», e cila për shumë gjana ngjiste me fashiot italiane, psh., në përdorimin e këmishave të zeza e edhe të vojit të recinit për kundërshtarët e vet. Zogu dyshonte, e kjo gja u fol mbas marrjes në pyetje të B. Walterit, që organizuesi i atentatit të Parlamentit ishte Avniu.

Tue marrë shkas prej funeralit të A. Rustemit, të zhvilluem në Vlonë me 1 maj 1924, opozita filloi kryengritjen po prej këtij qyteti. Ai që katër vjetë mâ parë ishte festue si shpëtuesi i kombit, tash bâhej shkak i çlirimin e vendit prej nji klike feudale. Duhet thanë që Luigj Gurakuqi, i cili kishte ndër deje ndjenja demokratike, nuk e priti mirë nisjen e revoltës, siç dishmon në kujtimet e veta P. Anton Harapi, por tashma alea jacta est - zari ishte gjuejtë e opozita e kishte shkapërcye Rubikonin ase Lumin e Vlorës prej kah trazinat pushtuene mbarë vendin.

Kurse Zogu veproi me mend, iku prej Tiranet për në Homesh tue shmang nji gjakderdhje të kotë mes shqiptarësh. Gati-gati të njajtën gja bâne edhe «revolucionarët» në pragun e Krishtlindjeve t'po atij vjeti, atëherë kur Zogu u kthye triumfues tue pru «legalitetin» në Tiranë.

E un tashti u gjindshe para vorrit t’atij Verlacit që prej prillit të vjetit 1939 deri në dhetor të vjetit 1941 do të merrte në dorë qeverinë shqiptare, në nji kohë të vështirë e të pakuptueshme, para vorrit t'atij që, simbas kontit Ciano: lexoi «si $i$ lodhun e si i pa mbushun mendjet» fjalimin me rasën e ofrimit të kunorës shqiptare Mbretit t'Italís.

Duhet thânë se edhe Verlaci e ka dashtë vendin e vet, mbasi nuk mund të gjykohet askush si i mbrapshtë vetëm prej përkatësís së rangut, pasunisë apo thjesht prej klisheve historike, kuptohet që mendësia e tij e ka shtërngue me e dashtë Shqipnín në nji mënyrë krejt të veçantë, e cila i ka kushtue shtrenjtë, gja që e tregon edhe vorri i tij i harruem prej shqiptarve. 